\title{
The Impact of Female Labor Participation on Household Savings Rate
}

\author{
Xiaobing Liu1, Manhong Liu², Yu Ma' \\ ${ }^{1}$ Entrepreneurship School, China Women's University, Beijing, China \\ ${ }^{2}$ School of Finance, Renmin University of China, Beijing, China \\ Email: csulxb2008@163.com
}

How to cite this paper: Liu, X. B., Liu, M. H., \& Ma, Y. (2021). The Impact of Female Labor Participation on Household Savings Rate. American Journal of Industrial and Business Management, 11, 131-156. https://doi.org/10.4236/ajibm.2021.112009

Received: December 7, 2020

Accepted: February 2, 2021

Published: February 5, 2021

Copyright $\odot 2021$ by author(s) and Scientific Research Publishing Inc. This work is licensed under the Creative Commons Attribution International License (CC BY 4.0).

http://creativecommons.org/licenses/by/4.0/

(c) (i) Open Access

\begin{abstract}
The high savings of Chinese families is a widely concerned issue. This paper attempts to explain the high savings of Chinese families from the perspective of female labor participation. Firstly, the relationship between female labor participation and household savings rate is theoretically discussed, and then an empirical test is conducted using the 2017 China Household Financial Survey data. In order to overcome the endogenous influence, the labor participation rate of other married women in the same community and the same age group is used as a tool variable for labor participation of married women in the family, and the influence of labor participation of married women on household savings rate is empirically tested. The results of the study show that labor participation of married women significantly increases household savings rates. Heterogeneity analysis found that married women's labor participation had a significant impact on the 20- to 30-year-old female family, university and higher education levels, and the savings rate of families who would like be with two children. Further research found that married women's labor participation in promoting the increase in household savings rate is due to a significant increase in household income levels, while household consumption levels have not changed significantly. At the same time, the current female labor participation did not significantly reduce the family's preventive saving motivation, but further increased the household savings rate. This paper provides a new perspective for understanding the high savings of Chinese families and can provide a reference for future policy development.
\end{abstract}

\section{Keywords}

Married Women, Household Savings Rate, Labor Participation 


\section{Introduction}

In recent years, China's economic growth rate has been slowing down, and the economic growth rate has dropped from $10.4 \%$ in 2010 to $6.6 \%$ in 2018 . The pattern of economic growth mainly depends on investment demand and import and export is difficult to sustain. Since the reform and opening up, China has invested a large amount of fixed assets, especially those represented by real estate, infrastructure and manufacturing. While promoting rapid economic growth, it has also led to the market's demand for investment has become saturated. The escalating trade war between China and the United States has further aggravated the instability of China's foreign trade export situation. Therefore, in the context of the current decline in investment demand and the weak economic environment of import and export trade, it is particularly important for consumer demand to drive economic growth.

Figure 1 depicts the changes in China's final consumption rate, household consumption rate, and savings rate from 2011 to 2015. ${ }^{1}$ As can be seen from Figure 1, China's household consumption rate and final consumption rate are slowly increasing. The household consumption rate has increased from $29.07 \%$ in 2011 to $39.31 \%$ in 2015 . The final consumption rate has increased from $40 \%$ in 2011 to $54 \%$ in 2015. During the same period, although the savings rate of Chinese residents was gradually decreasing, the decline was small. In 2015, the savings rate was still as high as $46.67 \%$. According to World Bank data, the world average household consumption rate in 2015 was 58\%. Among them, the average household consumption rate in high-income countries is $60 \%$, and the average household consumption rate in low-income countries is $78 \%$. In the same period, the Chinese household consumption rate is only $39 \%$, which is not only lower than the average consumption rate of high-income countries, but also lower than the low-income countries.

Household consumption rates continue to be sluggish and the savings rate remains high. Consumer demand and economic growth have not formed a coordinated development, seriously affecting and restricting the development of China's economy (Chen et al., 2014). As household consumption and savings have become more and more important to the economy, research on these issues has become increasingly important. In the literature, when studying the factors affecting the household savings rate, the following aspects are mainly carried out: First, based on preventive saving motives, such as family social security, medical insurance participation, and pension insurance participation (Blanchard \& Giavazzi, 2006; Chamon \& Prasad, 2010; He et al., 2008; Gao, 2010; Ma \& Zhou, 2014); Second, the level of financial development and cultural concepts (Kuijs, 2005; Aziz \& Cui, 2014; Ye, 2000; Hang, 2009); Third, the perspective of income distribution (Yang \& Zhu, 2007; Chen, 2012; Gan, et al., 2018); Fourth, family demographics and household head experience (Wei ${ }^{1}$ The data comes from the "China Statistical Yearbook" over the years. The latest data is as of 2015, because the 2018 China Statistical Yearbook only provides information on national accounts for 2015. 


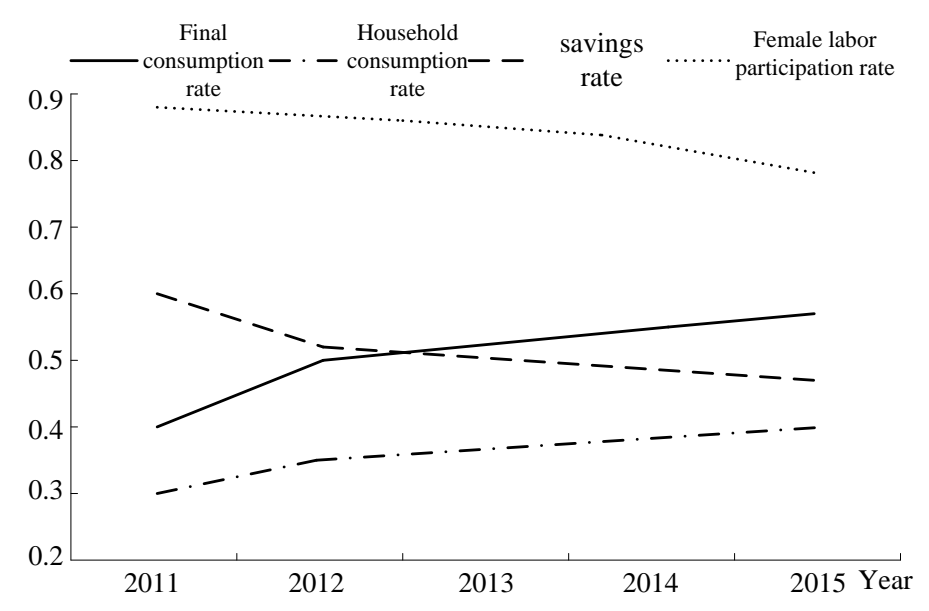

Figure 1. Chinese residents' final consumption rate, consumption rate, savings rate ${ }^{2}$ and labor participation rate of married women ${ }^{3}$.

\& Zhang, 2011; Cheng \& Zhang, 2011; Su et al., 2016); Fifth, changes in housing demand and housing prices (Chen \& Qiu, 2011; Chen \& Yang, 2013; Li \& Huang, 2015) and so on. Judging from the existing literature, there is very little research on the household savings rate from the perspective of labor participation of married women, which has become the direction of this article.

The female labor participation rate of Chinese women has long been at the forefront of the world. According to the statistics of the World Labor Organization in 2016, the female labor participation rate of China is 63\%, which is much higher than the female labor participation rate of the world's other major economies (56\% in the US, 55\% in Germany, 51\% in France, $49 \%$ in Japan, and $27 \%$ in India). How do married women participate in labor, and how will household consumption, income and savings change? In theory, married women's labor participation as a source of insurance for household income fluctuations (Dynarski et al., 1997; Monteiro, 2008) can reduce the family's preventive savings motives. The labor participation rate of Chinese women is so high, the level of household savings is still high, and the motivation for preventive savings does not seem to be reduced by female labor participation. From the perspective of realization, on the one hand, married women participate in labor, get wage income, and the total income of the family will increase; on the other hand, after women participate in labor, the level of household consumption may increase with the increase of income. The increase in income brought by labor participation of married women is greater than the increase in consumption, and the household savings rate increases. The increase in income brought by labor participation of married women is lower than the increase in consumption, and the ${ }^{2}$ The final consumption rate of residents in Figure 1 is defined as the proportion of total personal consumption and government consumption to the GDP of the year; the household consumption rate is defined as the proportion of total personal consumption to the GDP of the year; the savings rate is defined as the proportion of household savings deposits to GDP. The data comes from the China Statistical Yearbook.

${ }^{3}$ Based on the 2011, 2013 and 2015 CHFS data, the labor participation rate of married women in China is calculated. 
household savings rate is lower. Are married women involved in labor, and does household consumption and income levels increase at the same time? How does the household savings rate change? This is the motivation for further research in this article.

This paper uses the latest Chinese household financial survey data to study the impact of married women's labor participation on household savings rate from a micro perspective. Compared with the existing literature research, the contribution of this paper may be reflected in the following four aspects: First, it provides a new perspective to analyze the Chinese household savings rate and enriches research in this area. Secondly, using the labor participation rate of other married women in the same age group in the same community (or village) as the instrumental variable of labor participation of married women, endogenous identification of the instrumental variables in this paper makes the estimation results more reliable. Thirdly, this paper discusses in detail the differences in the impact of married women's labor participation on the savings rate of different groups. Finally, it further analyzes the reasons why the labor participation of married women promotes the increase of household savings rate.

The rest of the rest is arranged as follows: The second part reviews the relevant literature of this article; the third part is the theoretical model analysis; the fourth part is the model setting and variable description; the fifth part is the empirical result analysis; the sixth part is the robustness test; the seventh part is the heterogeneity analysis; the eighth part is the further discussion Finally, conclusions and countermeasures.

\section{Literature Review}

The literature closely related to this article includes two aspects: On the one hand, it studies the impact of labor participation of married women on household savings rate, mostly based on household consumption and income; on the other hand, it is the main literature related to household savings rate.

There is less literature on the direct study of married women's labor participation rate on household savings, and its indirect research mainly involves family income and consumption. Dynarski et al. (1997) found that when a family faces income fluctuation, the wife's labor participation in income can smooth the current consumption level. Attanasio et al. (2005) argue that in the life-cycle model of savings and labor supply, women pull power supply as an insurance mechanism to hedge income uncertainty risks, and this effect will be greater when households face external lending constraints. Low (2005) analyzes labor supply and savings under a partial equilibrium framework. The results show that when the labor supply elasticity is large, household consumption changes are more likely to occur when working hours are out of life, and labor supply has an ambiguous impact on preventive savings: On the one hand, individuals increase savings based on preventive motivation; on the other hand, prevent future devaluation of wealth and reduce savings, and household savings can be adjusted 
through labor supply. Under the general equilibrium framework, Marcet et al. (2007) and Pijoan-Mas (2006) make the supply of labor to the endogenous, the existing of labor income uncertainty risk results in total savings below the level of savings when the market clears. Monteiro (2008) studied the impact of special risks on savings and employment in a small open economy in which a husband and wife form a family. It is found that in families with high income uncertainty, the probability of the wife participating in the labor market is greater, and at the overall level, employment and savings are negatively correlated. Based on the survey data of farmers in 9 counties of 3 provinces in 2009, Yi et al. (2014) empirically analyzed the impact of migrant workers on household savings rate. The results show that farmers' migrant workers are negatively related to household savings rate, and migrant workers can share family risks, weaken the family's preventive savings motives. Fehr et al. (2016) derived a family formation model and concluded that the rise in marriage risk has a significant positive impact on personal savings. When the likelihood of getting married declines, young singles will foresee that they may not be able to enjoy the benefits of marriage (such as insurance and economies of scale). Therefore, they must establish preventive savings to provide insurance against life-cycle risks. The above research conclusions show that the increase in household labor supply weakens the family's preventive saving motives and makes the household saving rate decline.

Since the reform and opening up, China's household savings rate has remained high, and domestic and foreign scholars have explained it from different angles. First, that bases on life cycle theory (Modigliani, 1970; Modigliani \& Cao, 2004; Lin, 2012). Theoretical predictions show that the savings rate increases with the proportion of the working-age population in the total population, and with the arrival of China's aging population and low fertility rate, China's household savings rate has not decreased significantly (Chamon \& Prasad, 2010). Second, the precautionary savings motive is combined with rising income uncertainty (Blanchard \& Giavazzi, 2006; Chamon \& Prasad, 2010). Since 2003, the Chinese resident pension system and the public health care system have improved, but during the same period, the proportion of household savings in disposable income has risen sharply. He et al. (2008) used the data of urban household surveys from 1995 to 1999 to study the impact of pension reform policies on China's household savings rate. The results show that pension wealth has a significant substitution effect on household savings. Ma \& Zhou (2014) used two phases of China's follow-up survey data to study the impact of new rural pension insurance participation on household savings. It was found that the participation of new rural insurance did not have a significant impact on household savings. Gao (2010) based on the micro-farm household data of the eight provinces, it is concluded that the participation of farmers in the new rural cooperative medical care will significantly reduce the family's savings level. Third, the level of financial development is low (Kuijs, 2005; Aziz \& Cui, 2014). The conclusion of this study is difficult to explain that 
the household savings rate remains high. The reason is that China's financial market is constantly improving, residents' investment channels are continuously enriched, and the household savings rate is still high. Fourth, that is about cultural factors (Ye, 2000; Hang, 2009). Cultural norms often persist and are difficult to change in the short term. Therefore, cultural factors are difficult to explain the high savings rate of our residents at this stage. Fifth, that is based on the perspective of income distribution of residents. Excessive household income gap is an important reason for the decline in household consumption and the increase in savings rate (Yang \& Zhu, 2007; Chen, 2012; Gan, et al., 2018). Jin et al. (2011) found that one of the reasons for the high household savings rate in China is caused by income disparity and social inequality. People accumulate wealth for the pursuit of higher social status and reduce the consumption level of households. Sixth, that is from the perspective of the family population structure, the experience of the head of the household, and so on. Su et al. (2016) believe that the number of unmarried members in the family is an important reason for promoting the high savings rate of the family. Unmarried men have a greater impact on the household savings rate than unmarried women. Wei \& Zhang (2011) believes that the increase in gender imbalance has led to increased competition in the marriage market, which has led families to delay consumption and increase savings. Cheng \& Zhang (2011) used the three-year famine of China from 1956 to 1961 as a natural quasi-experiment, empirically analyzed the impact of the famine experience on the household savings rate, and found that the more severe the famine population, the higher the household savings rate. Seventh, that is the theory of the effects of consumption habits. Seekin (1999) found that households are affected by consumption habits, and residents are facing a gradual decline in consumption levels as they face constant changes in income, resulting in an increase in household savings rates. According to Carroll et al. (2000), under the influence of consumer inertia, expenditure fluctuations are relatively flat and will not change in the short term. Hang (2009) empirically found through the data of rural household survey that habit formation is an important explanatory variable affecting household consumption. Huang \& Zong (2014) believe that Chinese urban residents have significant habitual effects on food consumption. Zhang \& Ling (2015) found that the residents' preventive savings motives doubled when they did not control the habit effect.

Some scholars analyze the high savings rate of Chinese households from the perspectives of housing demand and housing prices. Chen \& Qiu (2011) analyzed through theoretical models that the rapid growth of housing prices has increased the demand for investment housing in high-income families, further pushing up housing prices, making the younger generation increase savings for high housing prices. Based on the data of urban household surveys of the $\mathrm{Na}$ tional Bureau of Statistics, Chen \& Yang (2013) explored the reasons for the high savings rate of Chinese residents from the perspective of land supply and 
housing market prices. The result also showed that residents had to save for excessive housing prices. Li \& Huang (2015) used the Chinese household finance survey data to draw similar conclusions.

The above literature analyzes the current situation of China's household savings rate from different angles or aspects, but rarely studies from the perspective of labor participation of married women. Based on the latest China Household Financial Survey data, this paper empirically analyzes the impact of married women's labor participation on China's household savings rate. The results of this study show that married women's labor participation significantly increases the household savings rate. Further research found that married women participate in labor, the income level of the family has increased significantly, but the level of household consumption has not changed significantly; the labor participation of married women not only does not significantly reduce the family's preventive saving motivation, but also enhances the family's prevention savings motivation.

\section{The Theoretical Model}

Based on the research of Yoshikawa \& Ohtaka (1989), this paper constructs a family selection model. Since married women participate in labor during the period from marriage to retirement age, only the savings and consumption behavior of the family during this period are considered, and the following assumptions are made: 1) The time of married women is divided into two periods, labor and leisure; the sum of labor time and leisure time is assigned to 1 , labor time is $l_{1}$, and leisure time is $l_{2}$, ie $\left.\left(1-l_{1}\right) .2\right)$ The market interest rate is $r$, where $0<r<1$, regardless of the impact of inflation. 3 ) When married women participate in labor, the family's savings level is $S_{1}$; when married women do not participate in labor, the family savings level is $S_{2}$. The consumption levels of the family in the two periods are $\mathrm{c} 1$ and $c_{2}$ respectively, and the wage income of the husband in the two periods is $y_{1}$ and $y_{2}$ respectively. It is assumed that the husband participates in the labor market in both periods and the wage income remains unchanged, ie $y=y_{1}=y_{2}$. 4) The wage rate of married women participating in labor is $\mathrm{W}$, there is no wage in leisure, and the change in wage rate is not considered. 5) The total income of the family has no income other than the wage income of the wife and husband. 6) In order to simplify the period, it is assumed that married women participate in the labor market in the first period, and in the second period of leisure, that is, they do not participate in labor in leisure period. From the above assumptions:

When a married woman participates in labor, the budget constraint of the first period is: $y_{1}+w l_{1}-c_{1}-s_{1}=0$. When a married woman does not participate in labor, the budget constraint of the second period is:

$y_{2}+(1+r) s_{1}-c_{2}-s_{2}=0$. According to economic theory, it is assumed that married women can get utility from consumption and leisure, and labor. So set the utility function: 


$$
U=\sum_{t=1}^{2} u\left(c_{t}, l_{t}\right)
$$

The model uses the Cobb-Douglas utility function and assumes that the marginal utility of married women in labor and leisure is constant, $a+b=1$. That is: $u\left(c_{t}, l_{t}\right)=c_{t}^{a} l_{t}^{a}$, to maximize the utility of married women under given constraints.

Further, a utility function of the objective function is given, and corresponding constraints are given according to the above assumptions.

$$
\begin{array}{ll}
\max U=c_{1}^{a} l_{1}^{b}+c_{2}^{a} l_{2}^{b} & \\
\text { s.t } & l_{1}+l_{2}=1, a+b=1 \\
& y_{1}+w l_{1}-c_{1}-s_{1}=0 \\
& y_{2}+(1+r) s_{1}-c_{2}-s_{2}=0
\end{array}
$$

According to the objective function and constraints, the consumption of married women in labor and the consumption of $c_{1}$ and $c_{2}$ when not participating in labor can be obtained:

$$
\text { saving }=1-\frac{\frac{a}{b} w l_{1}^{b}\left[\left[\left(\frac{l_{1}}{1-l_{1}}\right)^{-b}(1+r)\right]^{\frac{a}{a-1}}+\left[\left(\frac{l_{1}}{1-l_{1}}\right)^{-b}(1+r)\right]\right]}{\left[\left(1-l_{1}\right)^{b-1}-\left[\left(\frac{l_{1}}{1-l_{1}}\right)^{-b}(1+r)\right]^{\frac{a}{a-1}} l_{1}^{b-1}\right]\left(2 y+w l_{1}\right)}
$$

Here, using the idea of the limit, when $l_{1}$ approaches 1 , it can be approximated that married women participate in the labor market, and the household savings rate at this time is:

$$
\text { saving }_{1}=\lim _{l_{1} \rightarrow 1} \text { saving }=1-\frac{\frac{a}{b} w\left[[(1+r)]^{1-\frac{1}{b}}\right]}{\left[1-[(1+r)]^{1-\frac{1}{b}}\right]\left(2 y+w l_{1}\right)}
$$

When $l_{1}$ approaches 0 , it can be approximated that married women are not involved in the labor market, and the household savings rate at this time is:

$$
\text { saving }_{2}=\lim _{l_{1} \rightarrow 0} \text { saving }=1-\frac{\frac{a}{b} w[(1+r)]}{2 y\left[1-[(1+r)]^{1-\frac{1}{b}}\right]}
$$

Based on the above derivation, we can find saving $1>$ saving $_{2}$.

Assuming that the market interest rate remains the same, the husband's wage income is unchanged and the married woman is separated from work and leisure in the two periods. The theoretical deduction shows that the married woman has a higher household savings rate when she participates in labor than the family who does not participate in labor. From the derived savings rate expression, the household savings rate is closely related to the husband's income, 
the wage level of married women and working hours. Next, the impact of married women's labor participation on household savings rate will be analyzed through empirical analysis.

\section{Models and Variables}

\section{1) Model setting}

In order to examine the impact of married women's labor participation on household savings, refer to the existing literature and establish the following measurement model:

$$
\text { Saving }_{i}=a_{0}+\alpha_{1} * F L P_{i}+\alpha_{2} X_{i}+\mu_{i}
$$

Saving $_{i}$ represents the savings rate of the $i$-th family. $F L P_{i}$ indicates the situation in which the $i$-th family married women participate in labor. If they participate in labor, the value is 1 , otherwise the value is $0 . X_{i}$ is a control variable, including individual characteristic variables, family characteristic variables, and regional characteristic variables. $\mu_{i}$ is the residual term.

\section{2) Data and variables}

The data in this paper is from the China Household Finance Survey (CHFS) conducted by Southwestern University of Finance and Economics in 2017. CHFS surveyed 29 provinces/cities/autonomous regions except Xinjiang, Tibet, Hong Kong, Macao and Taiwan, which was representative at the national, urban and rural levels. The data captures demographic characteristics, household wealth, income, insurance, and employment information for households. To inquire in detail about the work and income information of family members, including the industry, nature and reasons of unemployment, as well as detailed records of the family's income and consumption, providing a reliable data support to study the issues of women's labor participation and household savings rate. The CHFS data adopts scientific and random sampling methods, and the survey data has good representativeness and high data quality (Gan et al., 2012). Some of the main variables are explained below.

a) Savings rate. The savings rate is the main explanatory variable of this paper. To increase the robustness and reliability of the empirical results, reference to the existing literature, and three definitions of savings rate are given. The first definition is based directly on the meaning of economics, using the family's total income for the year minus the household's consumption, and divided by the family's total income. Among them, household consumption ${ }^{4}$ includes non-durable goods consumption such as food, daily necessities, communication fees, cultural entertainment, transportation expenses, and education and medical expenses; family income includes property income, wage income, transfer income, and operating income. The expression for savings rate 1 is as follows:

\footnotetext{
${ }^{4}$ According to the questionnaire, household consumption mainly includes: food expenditure, daily living expenses, daily necessities, communication expenses, cultural and entertainment expenses, beauty expenses, local transportation expenses, purchase of clothing expenses, housing maintenance expenses, education expenses, and medical expenses.
} 
Saving $_{1}=($ Total Income - Consumption Expenditure $) /$ Total Income

Because of the contingency and suddenness of education expenditure and medical expenditure, the family's expenditure is very rigid. For the sake of stability, this paper draws on the practices of Ma \& Zhou (2014) and Su et al. (2016) to give the second definition of household savings rate, using the total income of the family minus the regular consumption of the family divided by the family income. That is, household consumption expenditure minus medical expenditure and education expenditure as the household's regular expenditure, the expression of saving rate 2 is as follows:

$$
\begin{aligned}
\text { Saving }_{2}= & {[\text { Total Income }-(\text { Consumption Expenditure }-(\text { Medical Expenditure }} \\
& + \text { Education Expenditure }))] / \text { Total Income }
\end{aligned}
$$

Further, in the robustness test section, the third definition of the savings rate is given. Drawing on the practices of Deaton \& Paxson (1994) and Chamon \& Prasad (2010), the savings rate is defined as the logarithm of household income minus the logarithm of household consumption expenditure.

$$
\text { Saving }_{3}=\operatorname{Ln}(\text { Household income })-\operatorname{Ln}(\text { Household consumption })
$$

In the process of empirical analysis, the savings rate 1 and savings rate 2 were taken as the main regression results.

b) Married women labor participation. This article strictly defines the labor participation of married women. Considering the legal marriage and retirement age of Chinese women, the age of married women is limited to 20 - 55 years old. According to the practice of Ma et al. (2017), the labor participation of married women is defined as an individual with a job, or the individual who has no job is a married woman who does not find a job, is not in the working due to seasonal reasons, and will meet the above conditions that here is defined as labor participation, the value is 1 , otherwise it is 0 .

c) Control variable. We refer to the literature on the study of household savings rate, and select the following control variables, including individual characteristic variables, family characteristic variables and regional characteristic variables of married women. Among them, the individual characteristic variables include: the age of the married woman, the years of education of the married woman, the health level of the married woman, the household registration of the head of the household, and the salary income of the husband; Family characteristic variables include: number of children under the age of 3 , number of children aged $4-6$, number of children aged $7-15$, family members participating in endowment insurance, family members participating in medical insurance, unmarried boys, family size, old-age dependency ratio, having their own housing, deposit account balance; Regional variables include: average consumption levels of communities, house prices in urban area, and provincial control variables.

In the process of processing data, in order to avoid the impact of outliers, refer 
to the practices of Li \& Huang (2015), Wan et al. (2003), and exclude the sample with total family income less than or equal to 0 , and set the upper limit of the household savings rate to $100 \%$, the lower limit is set to $-200 \%$, and the total sample size obtained is 19,613 .

As can be seen from Table 1, according to different definitions of savings rate, the average household savings rate in China is $13.48 \%$ and $34.12 \%$, respectively, indicating that China's household savings rate is higher. The average household consumption level is 47,900 yuan. The labor participation rate of married women in the family is $65.3 \%$. The average age of married women is about 43.27 years old, and the average years of education is 9.8 years, which indicates that the education level of married women in China is generally low. The average health level of married women is $0.14,0.32$, and 0.53 respectively, which indicates that the married women's health is above average. The number of children under 3 years old, the number of children aged $4-6$, and the number of children aged $7-15$ are $6.56 \%, 9.11 \%, 32.49 \%$, the average number of family members is $3-4$, and the proportion of unmarried boys in the family is $24.71 . \%$, the average old-age dependency ratio for each family is $4.10 \%$. The average hospitalization rate of family members was $9.34 \%$, and the participation rates of pension insurance and medical insurance respectively were $97.11 \%$ and $93.42 \%$, indicating that China's social security system has basically achieved full coverage. Married women have a self-owned housing ownership rate of $84.10 \%$, rural household registration ratio is $30.25 \%$. The average consumption level of the community is 47,900 yuan, and the evaluated housing price of the family is 15.7 million yuan.

Table 2 reports an overview of household savings rates. It can be seen that the rate of household savings when married women participate in labor is higher than the rate of household savings when they do not participate in labor. Taking the saving rate 2 as an example, the family saving rate of married women participating in labor is $38.87 \%$, which is significantly higher than the household saving rate of $25.19 \%$ when married women do not participate in labor. The difference between the two is $13.68 \%$.

\section{3) Endogenous analysis}

In model (3), whether married women participate in labor may be endogenous. On the one hand, there is the problem of missing variables. Unobservable variables such as individual consumption habits, local customs, culture, and individual preventive saving motives may affect whether married women participate in labor and affect household savings and consumption behaviors, resulting in endogeneity. On the other hand, syndication can cause endogeneity. The higher the household savings rate, the greater the proportion of household income is over than the household consumption in the current year. When the household income level is too high, it will inhibit the labor participation of family members, and vice versa.

In order to overcome endogeneity, this paper uses the instrumental variable method to make two-stage estimation. After again and again trial, the average 
Table 1. Descriptive statistics of variables.

\begin{tabular}{|c|c|c|c|c|}
\hline Variable name & Mean & $\begin{array}{l}\text { Standard } \\
\text { deviation }\end{array}$ & $\begin{array}{l}\text { Minimum } \\
\text { value }\end{array}$ & $\begin{array}{l}\text { Maximum } \\
\text { value }\end{array}$ \\
\hline Savings rate 1 & 0.1348 & 0.8167 & -2 & 1 \\
\hline Savings rate 2 & 0.3412 & 0.7718 & -2 & 1 \\
\hline Savings rate 3 & 0.3904 & 1.2864 & -2 & 1 \\
\hline Female labor participation & 0.6527 & 0.4761 & 0 & 1 \\
\hline Family size & 3.6229 & 1.3858 & 1 & 13 \\
\hline $\begin{array}{l}\text { Household consumption } \\
\text { (ten thousand yuan) }\end{array}$ & 4.7871 & 4.6292 & 0.0888 & 96 \\
\hline $\begin{array}{l}\text { Household income per capita } \\
\text { (ten thousand yuan) }\end{array}$ & 3.0896 & 3.9549 & 0 & 65 \\
\hline Medical insurance participation & 0.9711 & 0.1674 & 0 & 1 \\
\hline Pension insurance participation & 0.9342 & 0.2480 & 0 & 1 \\
\hline $\begin{array}{l}\text { Husband's wage income } \\
\text { (ten thousand yuan) }\end{array}$ & 4.1152 & 4.0536 & 0 & 120 \\
\hline Family member hospitalization & 0.0935 & 0.2912 & 0 & 1 \\
\hline Married women's education years & 9.7981 & 4.3178 & 0 & 22 \\
\hline Married woman age & 43.2654 & 8.9225 & 20 & 55 \\
\hline Number of children under 3 years old & 0.0656 & 0.2576 & 0 & 3 \\
\hline Number of children 4 - 6 years old & 0.0911 & 0.3000 & 0 & 3 \\
\hline Number of children aged 7 - 15 & 0.3249 & 0.5751 & 0 & 5 \\
\hline Unmarried boy & 0.2471 & 0.4313 & 0 & 1 \\
\hline Older dependency ratio ${ }^{(1)}$ & 0.0410 & 0.1045 & 0 & 0.6667 \\
\hline Married women are in poor health & 0.1426 & 0.4986 & 0 & 1 \\
\hline Married women are healthy & 0.3200 & 0.4665 & 0 & 1 \\
\hline Married women are very healthy & 0.5367 & 0.3497 & 0 & 1 \\
\hline $\begin{array}{l}\text { Deposit account balance } \\
\text { (ten thousand yuan) }\end{array}$ & 6.2310 & 24.6758 & 0 & 2002 \\
\hline Free housing & 0.8410 & 0.3657 & 0 & 1 \\
\hline $\begin{array}{l}\text { Average community consumption } \\
\text { (ten thousand yuan) }\end{array}$ & 4.7873 & 2.3681 & 0.5673 & 19.6528 \\
\hline Rural household registration & 0.3025 & 0.4593 & 0 & 1 \\
\hline City house price (ten thousand yuan) $)^{(2)}$ & 1.5688 & 1.5453 & 0.2353 & 6.7822 \\
\hline
\end{tabular}

${ }^{(1)}$ This article defines the family dependency ratio as the proportion of the number of elderly people over the age of 65 in the family to the total population of the family. ${ }^{(2)}$ The city's housing price data comes from the housing big data joint laboratory database, and other data comes from the 2017 China Household Financial Survey Data (CHFS).

Table 2. Overview of household savings rate.

\begin{tabular}{ccccccc}
\hline & \multicolumn{2}{c}{$\begin{array}{c}\text { Married women participate } \\
\text { in labor }\end{array}$} & $\begin{array}{c}\text { Married women do not } \\
\text { participate in labor }\end{array}$ & \multicolumn{2}{c}{ Full sample } \\
\cline { 2 - 7 } & Sample size & $\begin{array}{c}\text { savings } \\
\text { rate (\%) }\end{array}$ & Sample size & $\begin{array}{c}\text { savings } \\
\text { rate(\%) }\end{array}$ & Sample size & $\begin{array}{c}\text { savings } \\
\text { rate (\%) }\end{array}$ \\
\hline Savings rate 1 & 12,801 & 19.20 & 6812 & 2.72 & 19,613 & 13.48 \\
Savings rate 2 & 12,801 & 38.87 & 6812 & 25.19 & 19,613 & 34.12 \\
\hline
\end{tabular}


labor participation rate of other married women in the same community and the same age group was used as a tool variable for labor participation of married women in the family. Specifically select the following four married women's age groups, 20 - 30 years old, 31 - 40 years old, 41 - 50 years old, 51 - 55 years old. On the one hand, women of the same age group have a "peer effect" and a "panking effect", which are more susceptible to the influence of their peers. Neumark \& Postlewaite (1998) found that female labor participation in decision-making is positively correlated with whether other women participate in the labor market. Therefore, the higher the average level of labor participation of other married women in the same age group in the same age group, the greater the probability that married women in the family will participate in the labor market. On the other hand, the labor participation rate of other married women in the same age group is not directly related to the savings level of married female families. Therefore, it is appropriate to use the average labor participation rate of the same community and other women of the same age as the instrumental variable of labor participation of married women in the family.

\section{Estimated Results}

First, the impact of labor participation of married women on household savings rate is analyzed. The regression results of universal least squares method and instrumental variable method are shown in Table 3. In Table 3, column (1) is the regression result under the definition of savings rate 1 . The coefficient of labor participation of married women is significantly positive at the statistical level of $1 \%$, and the regression coefficient is 0.1071 . Column (2) replaces the savings rate indicator with a savings rate of 2 , which is the savings rate that does not include education and medical expenses. The results show that the impact of labor participation of married women in households on the savings rate is still significantly positive at the $1 \%$ statistical level, with a regression coefficient of 0.0956 .

Columns (3) and (4) are estimates based on the use of instrumental variables. The explanatory variable in column (3) is the household savings rate of 1 , and the explained variable in column (4) is the household savings rate. The endogenous results of the Durbin-Wu-Hausan test are reported at the bottom, and the p-values reject the endogenous problem of the model at a level of $10 \%$. The results of the first-stage regression show that the labor participation rate of other married women in the same community and the same age group has a significant impact on the labor participation of married women in the family at the $1 \%$ level, and the $\mathrm{F}$ value of the first stage is far greater than the critical value. According to the empirical value of Stock \& Yogo (2005), the critical value of F value greater than $10 \%$ is 16.38 . Therefore, it is appropriate to use the average labor participation rate of other married women in the same community and the same age group as tool variables, and there is no weak tool of variable selection problem. The estimation of the instrumental variables shows that the coefficient 
Table 3. Influence of labor participation of married women on household savings rate.

\begin{tabular}{|c|c|c|c|c|}
\hline & \multicolumn{2}{|c|}{ OLS } & \multicolumn{2}{|c|}{ 2SLS } \\
\hline & Savings rate 1 & Savings rate 2 & Savings rate 1 & Savings rate 2 \\
\hline Married women labor & $0.1071^{\star * \star}$ & $0.0956^{\star * \star}$ & $0.244^{\star * *}$ & $0.3076^{\star \star \star}$ \\
\hline participation & $(0.0117)$ & $(0.0115)$ & $(0.0727)$ & $(0.0711)$ \\
\hline Family size & $\begin{array}{c}0.0755^{* * *} \\
(0.0050)\end{array}$ & $\begin{array}{l}0.0764^{* * *} \\
(0.0049)\end{array}$ & $\begin{array}{c}0.0735^{* * *} \\
(0.0051)\end{array}$ & $\begin{array}{l}0.0731^{* * *} \\
(0.0050)\end{array}$ \\
\hline $\begin{array}{l}\text { Household income } \\
\text { per capita }\end{array}$ & $\begin{array}{l}0.0814^{* * *} \\
(0.0032)\end{array}$ & $\begin{array}{l}0.0659^{* * *} \\
(0.0027)\end{array}$ & $\begin{array}{l}0.0806^{* * *} \\
(0.0031)\end{array}$ & $\begin{array}{l}0.0643^{* * *} \\
(0.0026)\end{array}$ \\
\hline $\begin{array}{c}\text { Medical insurance } \\
\text { participation }\end{array}$ & $\begin{array}{l}0.1281^{\star * *} \\
(0.0392)\end{array}$ & $\begin{array}{c}0.1806^{\star * \star} \\
(0.0395)\end{array}$ & $\begin{array}{l}0.1164^{* * *} \\
(0.0405)\end{array}$ & $\begin{array}{c}0.1603^{* * *} \\
(0.0408)\end{array}$ \\
\hline $\begin{array}{c}\text { Pension insurance } \\
\text { participation }\end{array}$ & $\begin{array}{c}0.1878^{\star * *} \\
(0.0271)\end{array}$ & $\begin{array}{c}0.1356^{* * *} \\
(0.0268)\end{array}$ & $\begin{array}{c}0.1907^{\star * *} \\
(0.0277)\end{array}$ & $\begin{array}{l}0.1408^{* * *} \\
(0.0275)\end{array}$ \\
\hline Husband's wage income & $\begin{array}{c}0.0053^{* * *} \\
(0.0020)\end{array}$ & $\begin{array}{l}0.0039^{* * *} \\
(0.0017)\end{array}$ & $\begin{array}{c}0.0048^{* * *} \\
(0.0020)\end{array}$ & $\begin{array}{l}0.0034^{* *} \\
(0.0017)\end{array}$ \\
\hline $\begin{array}{l}\text { Family member } \\
\text { hospitalization }\end{array}$ & $\begin{array}{l}-0.0278 \\
(0.0190)\end{array}$ & $\begin{array}{c}0.1956^{* * *} \\
(0.0177)\end{array}$ & $\begin{array}{l}-0.0239 \\
(0.0192)\end{array}$ & $\begin{array}{l}0.1949^{* * *} \\
(0.0181)\end{array}$ \\
\hline $\begin{array}{l}\text { Married women's } \\
\text { education years }\end{array}$ & $\begin{array}{l}0.0123^{* * *} \\
(0.0018)\end{array}$ & $\begin{array}{l}0.0100^{* * *} \\
(0.0017)\end{array}$ & $\begin{array}{l}0.0111^{* * *} \\
(0.0019)\end{array}$ & $\begin{array}{l}0.0081^{* * *} \\
(0.0018)\end{array}$ \\
\hline Married woman age & $\begin{array}{l}0.0066^{* * *} \\
(0.0008)\end{array}$ & $\begin{array}{c}0.0051^{\star \star \star} \\
(0.0008)\end{array}$ & $\begin{array}{c}0.0067^{\star \star \star} \\
(0.0008)\end{array}$ & $\begin{array}{c}0.0051^{\star * *} \\
(0.0008)\end{array}$ \\
\hline $\begin{array}{c}\text { Number of children } \\
\text { under } 3 \text { years old }\end{array}$ & $\begin{array}{c}0.0338 \\
(0.0212)\end{array}$ & $\begin{array}{c}0.0200 \\
(0.0207)\end{array}$ & $\begin{array}{l}0.0687^{* * *} \\
(0.0231)\end{array}$ & $\begin{array}{c}0.0600^{* * *} \\
(0.0232)\end{array}$ \\
\hline $\begin{array}{l}\text { Number of children } \\
4 \text { - } 6 \text { years old }\end{array}$ & $\begin{array}{l}-0.0827^{* * *} \\
(0.0200)\end{array}$ & $\begin{array}{l}-0.0397^{* *} \\
(0.0201)\end{array}$ & $\begin{array}{l}-0.0711^{* * *} \\
(0.0211)\end{array}$ & $\begin{array}{l}-0.0381^{\star} \\
(0.0212)\end{array}$ \\
\hline $\begin{array}{c}\text { Number of children } \\
\text { aged } 7-15\end{array}$ & $\begin{array}{c}-0.0803^{\star * *} \\
(0.0112)\end{array}$ & $\begin{array}{c}-0.0478^{* *} \\
(0.0112)\end{array}$ & $\begin{array}{c}-0.0926^{* * *} \\
(0.0131)\end{array}$ & $\begin{array}{c}-0.0644^{* * *} \\
(0.0130)\end{array}$ \\
\hline Unmarried boy & $\begin{array}{l}0.0657^{\star * *} \\
(0.0134)\end{array}$ & $\begin{array}{l}0.0949^{\star * *} \\
(0.0129)\end{array}$ & $\begin{array}{l}0.0550^{\star * *} \\
(0.0148)\end{array}$ & $\begin{array}{c}0.0766^{\star * *} \\
(0.0144)\end{array}$ \\
\hline Older dependency ratio & $\begin{array}{c}0.0761 \\
(0.0525)\end{array}$ & $\begin{array}{l}0.2000^{\star * \star} \\
(0.0507)\end{array}$ & $\begin{array}{l}0.0949^{\star} \\
(0.0537)\end{array}$ & $\begin{array}{l}0.2286^{* * *} \\
(0.0521)\end{array}$ \\
\hline $\begin{array}{l}\text { Married women are } \\
\text { healthy }\end{array}$ & $\begin{array}{l}0.0205^{\star} \\
(0.0121)\end{array}$ & $\begin{array}{l}-0.0086 \\
(0.0118)\end{array}$ & $\begin{array}{c}0.0117 \\
(0.0124)\end{array}$ & $\begin{array}{l}-0.0207^{*} \\
(0.0121)\end{array}$ \\
\hline $\begin{array}{l}\text { Married women are in } \\
\text { poor health }\end{array}$ & $\begin{array}{l}-0.0791^{* * *} \\
(0.0192)\end{array}$ & $\begin{array}{c}0.0630^{* * *} \\
(0.0186)\end{array}$ & $\begin{array}{c}-0.0659^{* * *} \\
(0.0212)\end{array}$ & $\begin{array}{c}0.0866^{* * *} \\
(0.0205)\end{array}$ \\
\hline Deposit account balance & $\begin{array}{l}-0.0009 * * * \\
(0.0003)\end{array}$ & $\begin{array}{l}-0.0008^{* * *} \\
(0.0002)\end{array}$ & $\begin{array}{l}-0.0009^{* * *} \\
(0.0003)\end{array}$ & $\begin{array}{c}-0.0008^{* * *} \\
(0.0003)\end{array}$ \\
\hline Own housing & $\begin{array}{l}-0.0225 \\
(0.0160)\end{array}$ & $\begin{array}{l}-0.0326^{* *} \\
(0.0156)\end{array}$ & $\begin{array}{l}-0.0307^{*} \\
(0.0164)\end{array}$ & $\begin{array}{c}-0.0422^{* *} \\
(0.0161)\end{array}$ \\
\hline $\begin{array}{l}\text { Average consumption } \\
\text { of the community }\end{array}$ & $\begin{array}{l}-0.0204^{* * *} \\
(0.0033)\end{array}$ & $\begin{array}{l}-0.0173^{* * *} \\
(0.0032)\end{array}$ & $\begin{array}{l}-0.0196^{* * *} \\
(0.0035)\end{array}$ & $\begin{array}{c}-0.0155^{* * *} \\
(0.0033)\end{array}$ \\
\hline $\begin{array}{l}\text { Rural household } \\
\text { registration }\end{array}$ & $\begin{array}{l}-0.0466^{* * *} \\
(0.0153)\end{array}$ & $\begin{array}{l}-0.0209 \\
(0.0149)\end{array}$ & $\begin{array}{l}-0.0594^{* * *} \\
(0.0171)\end{array}$ & $\begin{array}{c}-0.0430^{* * *} \\
(0.0167)\end{array}$ \\
\hline City house price & $\begin{array}{l}-0.0194 \\
(0.0127)\end{array}$ & $\begin{array}{c}-0.0279 * * \\
(0.0076)\end{array}$ & $\begin{array}{l}-0.0161 \\
(0.0130)\end{array}$ & $\begin{array}{c}-0.0230^{*} \\
(0.0128)\end{array}$ \\
\hline Identity control variable & YES & YES & YES & YES \\
\hline Number of observations & 19610 & 19610 & 18869 & 18869 \\
\hline Batch and goodness & 0.199 & 0.147 & 0.194 & 0.132 \\
\hline F value & 55.4223 & 42.5039 & & \\
\hline One-stage F value & & & 36.84 & 36.84 \\
\hline Tool variable $t$ value & & & 21.85 & 21.85 \\
\hline DWH $\mathrm{Chi}^{2} / \mathrm{F}$ value & & & 3.8044 & 9.2713 \\
\hline P-value & & & 0.0511 & 0.0023 \\
\hline
\end{tabular}

Note: ${ }^{*}, * *, * *$ are indicated as $10 \%, 5 \%$, and $1 \%$, respectively, and the standard deviation of cluster heteroscedasticity is reported in parentheses. 
of labor participation of married women is significantly positive at the statistical level of $1 \%$, and the coefficients are 0.2444 and 0.3076 , respectively. The above regression results show that the labor participation of married women has a significant role in promoting the household savings rate: on the one hand, individual participation in labor will increase their income, and the total income of the family will rise significantly in the short term; on the other hand, the consumption effect obviously exists in the family of our country (Huang \& Zong, 2014), the consumption level will not change much in the short term. Therefore, family married women participate in labor, and the savings rate may increase in the short term. We will discuss in detail the changes in the participation of married women in labor, household income and consumption, and thus clarify the reasons for the increase in household savings rate.

From the perspective of control variables, the household's per capita income level has a significant positive effect on the savings rate, in line with the relative income hypothesis, which is consistent with the research results of Li Xuesong and Huang Yanyan (2015). As the age of married women increases, the household savings rate increases significantly, in line with the life cycle theory hypothesis. The higher the number of the children under age of 3 in the family, the higher the household savings rate level, and the statistical level of $1 \%$. This part of the family is small and will face more expenses in the future. Therefore, the current increase in household savings is in line with the precautionary savings theory. The number of children aged $4-6$ and 7 - 15 in the family is significantly negatively correlated with the household savings rate at $1 \%$. The reason may be that the children in the above two age groups are in kindergarten and primary and secondary schools, and the family often faces with large expenditures, the savings rate will be significantly reduced. Unmarried boys in the family significantly increase the household savings rate and verify the conclusions of Wei \& Zhang (2011). The relationship between old-age dependency and family savings rate is positively consistent with Liu \& Liu (2015). The higher the education of married women, the higher the savings rate of the family. The higher the healthy level of the wife, the lower the household savings rate, which is consistent with the research results of Ma \& Zhou (2014). At the same time, household deposit balances and owning homes can significantly reduce household savings rates. Households with more deposit balances tend to have less incentives for future preventive savings; families with house do not need to carry out high savings for future housing prices (Li \& Huang, 2015). The participation of pension insurance and medical insurance did not inhibit the household savings rate, and supported the conclusions of Ma \& Zhou (2014). The old-age insurance system of the social pooling mode has largely crowded out household consumption. The current pension system fails to provide a good guarantee, and residents still lack security in participating in pension insurance (Zhao et al., 2017). The average consumption level of other households in the community significantly inhibited the increase in household savings rate at the level of $1 \%$. Household 
consumption is easily influenced by neighbors and there is a comparison effect (Gali, 1994; Barnett et al., 2010). The increase in consumption inhibits the increase in household savings rates. Rural household registration has no significant effect on household savings rates. The urban housing prices affect the increase of household savings rate, which is inconsistent with the existing research conclusions. The reason may be that high housing prices make most of the households to use the income for housing loans, and consumption has not changed significantly due to the habit effect, thus causing the decline of household savings rate.

\section{Robustness Test}

In order to check the robustness of the previous estimation results, ${ }^{5}$ we will consider from the perspective of the sample, variable definition, model replacement and so on.

First, the sample robustness test. Engaging in agricultural labor is also regarded as a kind of labor participation. Because of the strong seasonality and autonomy of farming, married women may participate in both agricultural and non-agricultural labor. At the same time, the income level of families engaged in agriculture has little to do with whether the wife in the family participates in labor, but more depends on the size of the family's land and the crops they produce. Referring to the practice of Ma et al. (2017), the labor participation of married women was redefined and the "farm-working" individuals were treated. Removing the peasant individual and treat that the peasant individual is not involved in the labor, which also shows that the labor participation of the married woman significantly promotes the increase of the household savings rate at the $1 \%$ statistical level.

Second, the savings rate indicator is tested for robustness. Using the third measure of the previous savings rate, the logarithm of household income minus the logarithm of household consumption expenditure, the 0LS and 2SLS regression results are still stable under the definition of savings rate 3 .

Then, the Tobit model estimates. This paper sets the upper and lower limits of savings rate 1 and savings rate 2 to -2 and 1 . Although only a small portion of the sample data is compressed to the upper and lower limits, the Tobit model is used to test the robustness to prevent bias in the estimation results. Estimates show that married women participating in labor significantly increase the household savings rate at the $1 \%$ level.

Finally, PSM estimates. Because married women participate in labor with self-selection characteristics, in order to avoid selective bias in the sample, propensity score matching (PSM) is used to test the robustness of the estimation method. The model is re-estimated using neighbor matching and kernel matching, respectively. In order to ensure the reliability of the results, this paper tests whether the variables become more balanced before and after the

${ }^{5}$ Due to space limitations, all regression results of robustness are omitted here, and interest can be obtained from the author. 
matching, ${ }^{6}$ and whether the mean of the covariates still has significant differences between the experimental group and the control group. The results show that the covariates of the two matching methods basically pass the balance test, indicating that the model is suitable for the PSM method for robustness test. Estimates of the two matching methods show that married women participate in labor, and the household savings rate is significantly increased at the level of $1 \%$. The above estimation results show that the conclusions obtained in this paper are robust.

\section{Heterogeneity Analysis}

In this section, based on the different age groups of married women, different types of household registration, different levels of education, different income levels and whether the family has the willingness to have a second child, the impact of labor participation of married women on household savings rate is investigated. See Table 4.

Table 4. Heterogeneity analysis under different classification criteria.

\begin{tabular}{|c|c|c|c|c|}
\hline Regression sample & $\begin{array}{l}\text { Married women } \\
\text { labor participation } \\
\text { regression coefficient }\end{array}$ & $\begin{array}{l}\text { Standard } \\
\text { deviation }\end{array}$ & $\begin{array}{l}\text { Number of } \\
\text { observations }\end{array}$ & $\begin{array}{c}\text { goodness } \\
\text { of fit }\end{array}$ \\
\hline \multicolumn{5}{|c|}{ By age $\mathrm{A}$} \\
\hline $20-30$ & $0.5771^{\star * *}$ & $(0.1853)$ & 1881 & 0.197 \\
\hline $31-40$ & 0.5624 & $(0.4623)$ & 4234 & 0.165 \\
\hline $41-50$ & 0.2489 & $(0.2006)$ & 7854 & 0.195 \\
\hline $51-55$ & 0.1843 & $(0.1516)$ & 5170 & 0.207 \\
\hline \multicolumn{5}{|c|}{ By urban and rural B } \\
\hline Rural & 0.3198 & $(0.2039)$ & 55279 & 0.228 \\
\hline City & $0.2282^{\star * *}$ & $(0.0808)$ & 13290 & 0.207 \\
\hline \multicolumn{5}{|c|}{ According to education level C } \\
\hline Did not go to school & 0.9167 & $(0.6035)$ & 1232 & 0.169 \\
\hline primary school & 0.2016 & $(0.2090)$ & 4178 & 0.228 \\
\hline junior high school & 0.2653 & $(0.1817)$ & 6282 & 0.216 \\
\hline High school & 0.1496 & $(0.1668)$ & 3385 & 0.228 \\
\hline University and above & $0.4261^{\star * *}$ & $(0.1194)$ & 3792 & 0.219 \\
\hline \multicolumn{5}{|c|}{ By household income D } \\
\hline Low income $e^{(1)}$ & $0.2990^{* * *}$ & $(0.1485)$ & 4686 & 0.4257 \\
\hline medium income & $0.2472^{\star * *}$ & $(0.0640)$ & 9444 & 0.1365 \\
\hline High income & $0.0882^{\star}$ & $(0.0528)$ & 4739 & 0.1117 \\
\hline \multicolumn{5}{|c|}{ According to fertility wishes $\mathrm{E}$} \\
\hline Have a second child's will & $0.6336^{* * *}$ & $(0.2980)$ & 1002 & 0.254 \\
\hline No second child willingness & 0.4966 & $(0.3436)$ & 2537 & 0.174 \\
\hline
\end{tabular}

${ }^{(1)}$ In this paper, households with a minimum annual income of $25 \%$ are set as low-income families; $25 \%$ of households with the highest income are set as high-income families; middle-aged households are set. Note: ${ }^{\star},{ }^{*},{ }^{* *}$ indicate significant at $10 \%, 5 \%$, and $1 \%$, respectively, and the clustering heteroscedastic robust standard deviation is reported in parentheses. The following tables are similar except for special cases.

${ }^{6}$ In order to accept the length, the results of the balance test are not reported, and interested readers can request it from the author. 
First, Part A of Table 4 is grouped according to the age of married women to analyze the impact of labor participation of married women of different ages on household savings rate. The regression results show that the participation of married women in the 20 - 30 age group in the labor market will increase the household savings rate, which is significant at the $1 \%$ statistical level. The reason may be that married women of this age just got married and face the pressure of buying a house to buy a car and take care of their children, so this stage needs to save for future consumption. For women between the ages of $31-40$ and $41-50$, although women's participation in the labor market can increase the household savings rate, it is not significant at the $10 \%$ statistical level. Women in this age group are faced with the task of educating their children and supporting the elderly. The effect of household consumption expenditure may be greater than the effect of married women's participation in the labor market. The participation of married women in the 51 - 55 age group in the labor market will increase the household savings rate, but it is not significant at the $10 \%$ statistical level.

Second, Part B of Table 4 is grouped according to the urban and rural household registration of married women to examine the impact of labor participation of married women in urban and rural areas on household savings rates. Married women in urban areas participate in labor, and the household savings rate has increased significantly at the $1 \%$ statistical level. Married women in rural areas participate in labor, and the household savings rate does not change significantly at the $10 \%$ statistical level. Compared with households in urban areas, the income level and stability of rural households are relatively low, and the income earned by married women in the family participating in labor is more used for basic household consumption.

Thirdly, according to the education level of married women, the participation of married women in high school and below has no significant effect on the household savings rate. The influence of married women in universities and above on the household savings rate is relatively high sensitive. Part $\mathrm{C}$ of Table 4 shows that married women with university degrees can participate in labor, which can significantly increase the household savings rate. This is consistent with the findings of Zhang \& Zhang (2016).

Fourth, the impact of married women with different family incomes on household savings rates is also different. Part D of Table 4 indicates that for low-income families, married women participate in labor, and the household savings rate increases by $29.9 \%$, which is significant at the $5 \%$ statistical level. For middle-income families, the labor participation of married women is most sensitive to the impact of household savings rate. Compared with married women who do not participate in labor, the household savings rate of working married women will increase by $24.72 \%$ at a significant level of $1 \%$. For high-income families, the participation of married women in the labor market has the least effect on the household savings rate, and the household savings rate has increased by $8.82 \%$ at the $10 \%$ statistical level.

Fifth, we also examined the impact of married women's labor participation on 
household savings rates under the comprehensive second-child policy. To ensure the impact of the second child policy, this article limits the scope of the sample to less than or equal to one child, and the age range of married women is 20 - 45 years. Table $4 \mathrm{E}$ is divided into groups according to the family's second child's will. The regression results show that families with second-child wishes, married women participate in labor, household savings rate increases significantly at $1 \%$; families without second-child wishes, married women Labor participation has no significant effect on household savings rates. The results show that families with a second child's willingness are more likely to increase the current level of savings and prepare for future child spending.

\section{Further Analysis}

According to the above analysis, married women participate in labor, and the household savings rate increases significantly. What are the reasons why married women participate in labor to increase the household savings rate? We will analyze both theoretical and practical experience: on the one hand, through combing the literature, it is found that labor participation as an insurance mechanism for household income fluctuations reduces the family's preventive saving motives and makes the household savings rate decline. Contrary to this, the conclusion of this paper is that the labor participation of married women is increasing the savings rate of the family. The possible reason is that the labor participation of married women can promote the family's preventive saving motivation. We will empirically test the impact of sexual savings motivation on the labor participation of married women in family prevention. On the other hand, the factors directly related to the household savings rate are the consumption and income of the family. How does the labor participation of married women affect the income and consumption of the family? Next, we will further examine the impact of married women's labor participation on household consumption and income.

1) The impact of labor participation of married women on household consumption and income.

In Table 5, the ordinary least squares method and the two-stage least squares method are used to further analyze the influence of labor participation of married women on family income and consumption. Columns (1) and (2) are the effects of labor participation of married women on household consumption. The regression results of 2 SLS show that married women's labor participation reduces household consumption, but it is not significant at the $10 \%$ statistical level. At the same time, the D and F values of the DWH test are 2.1784 and 0.1403 , respectively. Acceptance of the model does not have the endogenous hypothesis. Therefore, the estimation results of the OLS in column (2) are further reported. After controlling other variables, the married women are Labor participation that promotes the household consumption, but it is not significant at the $10 \%$ statistical level. From the above regression results, it can be found that the labor participation of married women has no significant impact on household consumption. 
Table 5. Impact of labor participation of married women on household consumption and income.

\begin{tabular}{|c|c|c|c|c|}
\hline & (1) & (2) & (3) & (4) \\
\hline & $\begin{array}{c}\text { Household } \\
\text { consumption } \\
\text { (2sls) }\end{array}$ & $\begin{array}{c}\text { Household } \\
\text { consumption } \\
\text { (OLS) }\end{array}$ & $\begin{array}{l}\text { Household } \\
\text { income } \\
\text { (2SLS) }\end{array}$ & $\begin{array}{l}\text { Household } \\
\text { income } \\
\text { (OLS) }\end{array}$ \\
\hline $\begin{array}{l}\text { Married women labor } \\
\text { participation }\end{array}$ & $\begin{array}{c}0.0201 \\
(0.0592)\end{array}$ & $\begin{array}{l}-0.5356 \\
(0.3693)\end{array}$ & $\begin{array}{l}1.5891^{* * *} \\
(0.4352)\end{array}$ & $\begin{array}{c}0.0685^{* * *} \\
(0.0851)\end{array}$ \\
\hline Control variable & YES & YES & YES & YES \\
\hline Number of observations & 18869 & 19610 & 18869 & 19610 \\
\hline Goodness of fit & 0.334 & 0.333 & 0.865 & 0.861 \\
\hline One-stage $\mathrm{F}$ value & 36.84 & & 36.84 & \\
\hline Tool variable t value & 21.85 & & 21.85 & \\
\hline DWH Chi²/F value & 2.1748 & & 5.1813 & \\
\hline $\mathrm{P}$-value & 0.1403 & & 0.0228 & \\
\hline
\end{tabular}

Columns (3) and (4) in Table 5 reports the impact of labor participation of married women on their household income. Estimates of the instrumental variables in column (3) show that at $1 \%$ of the statistical level, labor participation of married women significantly increases household income. Married women participate in the labor market, household income levels increase significantly, and the DWH test rejection model does not have endogenous assumptions. The above results show that the participation of married women in the labor market can significantly increase the income level of the family.

Based on the results of Table 5, married women participate in labor. On the one hand, there is no significant change in household consumption levels, which further confirms the consumption habit effect of households in China, and household consumption does not change significantly in the short term (Carroll et al., 2000); on the other hand, the income level of the family has increased significantly. Therefore, the reason why married women participate in labor increases the household savings rate is that there is no significant change in household consumption levels, but income levels have increased significantly. The data in Table 5 is in the confidence interval of $10 \%$.

2) Does married female labor participation reduce the family's preventive savings motivation?

Studies have shown that family members participating in labor will expand the family's income source, disperse family risks, and weaken the family's preventive saving motivation (Yi et al., 2014). Married women's labor participation expands the source of family income, increases household income, and how does the family's motivation for preventive savings change? Although the CHFS questionnaire does not directly address the issue of preventive saving motivation, we can use the future education expenditure of family children, the stability of future work income, and the status of pension as a proxy variable for preventive saving motivation, and investigate the impact of the labor participation of mar- 
ried women in the prevention motivation of family savings. Households with children in high school and below will make preventive savings on future children's education expenditures; traditionally, working families in the sate-owned units face less unemployment risks, relatively stable income, and the preventive savings motivation for losing their jobs of these families in the future is weaker; the concept of raising children and preventing for the old age is still prevalent in some parts of China, especially in rural areas. Compared with families with sons, there is much more strong motivation of preventive savings for the families without sons to support the elderly. Specifically, estimate the following measurement model:

$$
\text { Saving }_{i}=\beta_{0}+\beta_{1} \text { FLP }_{i}+\beta_{2} \text { Previous }_{i}+\beta_{3} F L P_{i} * \text { Previous }_{i}+\beta_{4} X_{i}+\mu_{i}
$$

Saving $g_{i}$ is the household savings rate, measured by the savings rate of $1^{7}$ above. Previous is a proxy variable for households to prevent savings. Specifically, we use households with children who are in high school and below, work outside the state-owned units, and have no sons as substitute variables for preventive education savings, preventive unemployment savings, and preventive pension savings. FLP is the labor participation of married women, consistent with the previous definition. $X$ is the control variable that affects the household savings rate, which is consistent with the control variables of the former main regression, and will not be described again. The estimated results are shown in Table 6.

Table 6. Influence of Labor Participation of Married Women on Family Precautionary Saving Motivation.

\begin{tabular}{|c|c|c|c|}
\hline & (1) & $(2)$ & (3) \\
\hline Married women labor participation & $\begin{array}{l}0.3213^{\star * *} \\
(0.1118)\end{array}$ & $\begin{array}{l}0.7473^{* * *} \\
(0.3648)\end{array}$ & $\begin{array}{l}0.4152^{* *} \\
(0.1673)\end{array}$ \\
\hline Children are studying in high school and below & $\begin{array}{c}0.1049 \\
(0.0701)\end{array}$ & & \\
\hline Married women labor participation * & $-0.1949^{*}$ & & \\
\hline Children are studying in high school and below & $(0.1112)$ & & \\
\hline $\begin{array}{l}\text { The head of the household works outside the } \\
\text { national units }{ }^{(1)}\end{array}$ & & $\begin{array}{c}0.2908 \\
(0.2535)\end{array}$ & \\
\hline $\begin{array}{l}\text { Married female labor participation* head of } \\
\text { household working outside the national units }\end{array}$ & & $\begin{array}{c}-0.6323^{*} \\
(0.3620)\end{array}$ & \\
\hline Family without boys & & & $\begin{array}{c}0.1798 \\
(0.1149)\end{array}$ \\
\hline $\begin{array}{l}\text { Married women labor participation * } \\
\text { family without boys }\end{array}$ & & & $\begin{array}{l}-0.3105^{*} \\
(0.1649)\end{array}$ \\
\hline Control variable & YES & YES & YES \\
\hline Number of observations & 18869 & 18869 & 18869 \\
\hline Goodness of fit & 0.190 & 0.175 & 0.184 \\
\hline
\end{tabular}

${ }^{(1)}$ According to the 2017 China Family Finance Survey Questionnaire, taking the head of household working in state-owned enterprises, institutions, collective enterprises, and working in villages or communities to be defined as working within the national units.

${ }^{7}$ For the sake of robustness, this paper also estimates the savings rate 2 , and the results are consistent. In order to save space, the results were not reported. 
The regression results in Table 6 show that after the model (7) controls the nature of the children's high school and below, the nature of the work of the head of household, and whether the family has boys, the participation of married women in labor still has a significant effect on the household savings rate. Column (1) is a test of the motivation of preventive savings for children's education in the family. The results show that the family has children in high school and the following level have a positive effect on the household savings rate, but it is not statistically significant; the cross-term coefficient of married women's labor participation and children in high school and the following level is -0.1979 , which is significant at the $10 \%$ statistical level. The coefficient of labor participation of married women is 0.3213 , and the total effect coefficient is 0.1264 . The results show that married women participating in labor significantly improve their savings rate in the family whose children in high school and the following level. Column (2) is a precautionary savings test for household working income. The results show that the householder working outside the national units has a positive effect on the household savings rate. The estimated coefficient of the cross term is -0.6323 , which is significant at the statistical level of $10 \%$, the total effect coefficient is 0.115 . The estimation results show that married women's participation in labor does not reduce the preventive saving motivation of family stable work, but furtherly enhance. Column (3) is a test of household pension preventive savings motivation. The regression coefficient of cross-term is -0.2615 , and the total effect coefficient is 0.1047 . The same results show that labor participation of married women does not significantly reduce the family's motivation for preventive savings.

To sum up, the labor participation of married women has increased the income level of the family, but the consumption level of the family has not changed significantly. At the same time, the labor participation of married women did not significantly reduce the family's children's education preventive saving motivation, work stability preventive saving motivation and pension prevention saving motivation, but increased the family's preventive saving motivation, thus promotes the increase of household savings rate. .

\section{Conclusion}

This paper studies the relationship between labor participation and family savings of married women. In the theoretical model part, by constructing the mod$\mathrm{el}$, the family savings rate of married women participating in labor and leisure is derived. The empirical analysis section uses the 2017 China Household Financial Survey data to estimate the impact of married women's labor participation on household savings rates. In order to avoid the estimation bias caused by endogeneity, the labor participation rate of other married women in the same community and the same age group is used as the instrumental variable for estimation.

The main findings of this paper show that after controlling individual charac- 
teristics, family characteristics and regional characteristics, married women participate in the labor market, and the household savings rate increases significantly at $1 \%$ level. Changing the definition of saving rate, the definition of female labor participation and the re-adjustment of estimation methods, the estimation results are still unchanged. Heterogeneity analysis found that the individual's age, household registration, education level, family income level and the willingness of the two children, the impact of labor participation of married women on household savings rate is significantly different. Married female labor participation has a significant impact on the household savings rate in the 20 to 30 age group; compared to married women with agricultural household registration, participation in the labor market will increase the savings rate of non-agricultural married women families; Married women with or above university education background, the participation in the labor market will significantly increase the household savings rate; compared with high-income families, married women's labor participation is more sensitive to increasing the savings rate of low- and middle-income families; In the policy background of two children, the labor participation of marriaed women has significantly increased the savings rate of families willing with two children. Further analysis shows that married women participate in labor, household consumption levels have not changed significantly, and household income levels have increased significantly. At the same time, the labor participation of married women did not significantly reduce the family's preventive savings motives, but instead increased.

The research conclusions of this paper have certain reference value for policy making. At this stage, China's household savings rate is still at a relatively high level, and residents' consumption demand is insufficient, which seriously affects and restricts economic development and transformation. While expanding domestic demand and promoting household consumption, how to promote consumption through the increase in the employment rate of family members and the increase in income levels should become a concern matter to relevant departments. Chinese married women in the family participate in labor. On the one hand, the family's income level is raised, and the family's consumption level has not changed significantly. On the other hand, the increase in family labor members has not significantly reduced the family's preventive saving motivation. Therefore, when encouraging the married women to enter the labor market, the government should also focus on encouraging household consumption and improving the social security level of the residents, especially the protection of children's education, pension and employment, so as to reduce the family's preventive saving motivation. Therefore, it really plays a role in expanding domestic demand and stimulating economic growth.

Of course, the research in this article still has some flaws. First, factors such as nature, humanities, and ethnic groups in different regions may also have an impact on household savings, but this article does not reflect these various influencing factors well. These are the contents that need further refinement and in-depth research in the future. 


\section{Conflicts of Interest}

The authors declare no conflicts of interest regarding the publication of this paper.

\section{References}

Attanasio, O., Low, H., \& Sanchez-Marcos, V. (2005). Female Labor Supply as Insurance Against Idiosyncratic Risk. Journal of the European Economic Association, 3, 755-764. https://doi.org/10.1162/jeea.2005.3.2-3.755

Aziz, J., \& Cui, L. (2014) Explaining China's Low Consumption: The Neglected Role of Household Income. Rochester, NY: Social Science Electronic Publishing.

Barnett, R. C., Bhattacharya, J., \& Bunzel, H., (2010) Choosing to Keep up with the Joneses and Income Inequality. Economic Theory, 45, 469-496. https://doi.org/10.1007/s00199-009-0494-5

Blanchard, O., \& Giavazzi, F. (2006) Rebalancing Growth in China: A Three-Handed Approach. China \& World Economy, 14, 1-20.

https://doi.org/10.1111/j.1749-124X.2006.00027.x

Carroll, C. D., Overland, J., \& Weil, D.N. (2000) Saving and Growth with Habit Formation. American Economic Review, 90, 341-355. https://doi.org/10.1257/aer.90.3.341

Chamon, M. D., \& Prasad, E.S. (2010) Why Are Saving Rates of Urban Households in China Rising? American Economic Journal Macroeconomics, 2, 93-130. https://doi.org/10.1257/mac.2.1.93

Chen, B. K. (2012) Revenue Distribution and Chinese Residents Consumption-Theory and Empirical Research Based on China. Nankai Economic Research, No. 1, 33-49.

Chen, B. K., Chen, L., \& Tan, A. B. (2014) Understanding Under-Consumption in China: A Literature-Based Review. World Economy, No. 7, 71-83.

Chen, B. K., \& Yang, W. (2013) Land Supply, Housing Price and China Urban Residents Savings. Economic Research, No. 1, 97-107.

Chen, Y. B., \& Qiu, Z. S. (2011) How High Housing Prices Affect Residents' Saving Rate and Property Inequality. Economic Research, No. 10, 25-38.

Cheng, L. G., \& Zhang, Y. (2011) Is the Early Famine Experience Affecting People's Saving Behavior?-A New Interpretation of the High Saving Rate of Chinese Residents. Economic Research, No. 8, 119-132.

Deaton, A. S., \& Paxson, C. (1994). Saving, Growth and Aging in Taiwan. Cambridge, MA: National Bureau of Economic Research.

Dynarski, S., Gruber, J., Moffitt, R.A, \& Burtless, G. (1997) Can Families Smooth Variable Earnings? Brookings Papers on Economic Acitivity, 1997, 229-303. https://doi.org/10.2307/2534704

Fehr, H., Kallweit, M., \& Kindermann, F. (2016) Household Formation, Female Labor Supply and Savings. Scandinavian Journal of Economics, 184, 868-911. https://doi.org/10.1111/sjoe.12154

Gali, J. (1994) Keeping Up with the Joneses: Consumption Externalities, Portfolio Choice and Asset Prices. Journal of Money, Credit and Banking, 26, 1-8. https://doi.org/10.2307/2078030

Gan, L., Yin, Z. C., Jia, N., Xu, S., \& Ma, S. (2012) China Family Finance Survey Report 2012. Chengdu: Southwestern University of Finance and Economics Press.

Gan, L., Zhao, N. B., \& Sun, Y. (2018) Inequality in Income, Liquidity Constraints and 
China's Household Savings Rate. Economic Research, No. 12, 56-69.

Gao, M. T. (2010) New Rural Cooperative Medical Care and Farmers' Savings: An Empirical Study Based on Micropanel Data of Eight Provinces. World Economy, 33, 121-133.

Hang, B. (2009) The Behavior of Farmers' Buffer Reserve under the Habit of Forming. Economic Research, 44, 96-105.

He, L. X., Feng, J., \& Sato, H. (2008) The Impact of Endowment Insurance Reform on Household Saving Rate: Empirical Evidence from China. Economic Research, No. 10, 117-130.

Huang, Y. N., \& Zong, Q. Q. (2014) The Formation Effect of Consumption Habits of Chinese Urban Residents. Economic Research Journal, 49, 25-33.

Jin, Y., Li, H. B., \& Wu, B. Z. (2011). The Income Gap and Social Status Seeking: A Reason for a High Savings Rate. Economics (Quarterly), No. 2, 887-912.

Kuijs, L. (2005) Investment and Saving in China (English) (pp. 1-20). Rochester, NY: Social Science Electronic Publishing. https://doi.org/10.1596/1813-9450-3633

Li, X. S., \& Huang, Y. Y. (2015). The Mystery of Cracking China's High Savings Rate: An Interpretation of Changes in Population Age Structure. Population and Economy, No. 3.

Liu, K. H. \& Liu, Y. L. (2015) The Mystery of Cracking China's High Savings Rate: An Interpretation of Changes in Population Age Structure. Population and Economy, No. 3, 43-56. http://dx.chinadoi.cn/10.3969/j.issn.1000-4149.2015.03.005

Lin, G. (2012) Life-Cycle Hypothesis and The Chinese Saving Puzzle. Future \& Development, 35, 24-28. http://dx.chinadoi.cn/10.3969/j.issn.1003-0166.2012.01.006

Low, H. (2005) Self-Insurance in a Life-Cycle Model of Labor Supply and Savings. Review of Economic Dynamics, 8, 945-975. https://doi.org/10.1016/j.red.2005.03.002

Ma, G. R., \& Zhou, G. S. (2014) The Impact of New Rural Endowment Insurance on Household Savings: A Study Based on CFPS Data. Economic Research, 49, 43-54.

Ma, S., Li, X. L., \& Cai, D. L. (2017) Minimum Wage and Labor Participation of Married Women. Economic Research, 52, 153-168.

Marcet, A., Obiols-homs, F., \& Weil, P. (2007) Incomplete Markets, Labor Supply and Capital Accumulation. Journal of Monetary Economics, 54, 2621-2635.

https://doi.org/10.1016/j.jmoneco.2006.12.011

Modigliani, F. (1970) The Life Cycle Hypothesis of Saving and Intercountry Differences in The Saving Ratio. In W. A. Elits, M. F., Scott, \& J. N. Wolfe, (eds.), Growth and Trade: Essays in Honor of Sir Roy Harrod. Oxford: Oxford University Press.

Modigliani, F., \& Cao, S. L. (2004) The Chinese Saving Puzzle and The Life-cycle Hypothesis. Journal of Economic Literature, 42, 145-170. https://doi.org/10.1257/002205104773558074

Santos-Monteiro, P, (2008) Family Labor Supply and Aggregate Saving. Coventry: Department of Economics, University of Warwick.

Neumark, D., \& Postlewaite, A. (1998) Relative Income Concerns and The Rise in Married Women's Employment. Journal of Public Economics, 70, 57-183. https://doi.org/10.1016/S0047-2727(98)00065-6

Pijoan-Mas, J. (2006) Precautionary Savings or Working Longer Hours? Review of Economic Dynamics, 9, 326-352. https://doi.org/10.1016/j.red.2005.11.002

Seekin, A. (1999) Essays on Consumption with Habits Formation. Ph.D. Dissertation, Ottawa: Carleton University. 
Stock, J. H., \& Yogo, M. (2005) Identification and Inference for Econometric Models: Asymptotic Distributions of Industrial Variables Statistics with Many Instruments. Journal of the American Statistics Association, 89, 1319-1320.

Su, H. S., Lyu, W. H., \& Zhang, Y. F. (2016) The Influence of the Number of Unmarried Family Members on the Household Saving Rate-Based on the Research of CFPS Panel Data. Economic Science, No. 6, 75-88.

Wan, G. H., Shi, Q. H., \& Tang, S. M. (2003) Saving Behavior of Farmers in a Transitional Economy: An Empirical Study of Rural China. Economic Research, 1, 181-201.

Wei, S. J., \& Zhang, X.B. (2011) The Competitive Saving Motive: Evidence from Rising Sex Ratios and Savings Rates in China. Journal of Political Economy, 119, 511-564. https://doi.org/10.1086/660887

Yang, R. D., \& Zhu, S. Z. (2007) Fairness and Efficiency Cannot be Both Horses?-Based on the Study of Residents' Marginal Propensity to Consume. Economic Research, 42, 46-58.

Ye, H. Y. (2000) On the Relationship between Liquidity Constraints, Short-Sighted Behavior and Weak Consumer Demand in China. Economic Research, No. 11, 39-44.

Yi, X. J., Zhang, B., \& Yang, B. Y. (2014) Revenue for Migrant Workers and Savings Behavior of Farmers: An Empirical Test Based on Rural Residents in China. China Rural Economy, No. 6, 41-55, 65.

Yoshikawa, H., \& Ohtaka, F. (1989) An Analysis of Female Labor Supply, Housing Demand and The Saving Rate in Japan. European Economic Review, 33, 997-1023. https://doi.org/10.1016/0014-2921(89)90010-X

Zhang, A. Q., \& Ling, C. (2015) The Study of the Precautionary Savings of Chinese Urban and Rural Residents under the Habit of Forming. Statistical Research, 32, 23-30.

Zhang, Z. Y., \& Zhang, M. H. (2016) The Relationship between Years of Education, Life Expectancy and Savings Rate under the Statutory Retirement System-And the Impact of Delayed Retirement on the Savings Rate of Residents. Contemporary Finance and Economics, No. 12, 44-54.

Zhao, Y. D., Wang, W., \& Liu, T. (2017) Aging Population, Endowment Insurance and Household Savings Rate. China Soft Science, No. 8, 156-165.

http://dx.chinadoi.cn/10.3969/j.issn.1002-9753.2017.08.016 